\title{
Intermediate results of isolated mitral valve replacement with a Biocor porcine valve
}

\author{
Giulio Rizzoli, MD \\ Tomaso Bottio, MD, $\mathrm{PhD}^{\mathrm{a}}$ \\ Vladimiro Vida, $\mathrm{MD}^{\mathrm{a}}$ \\ Georgios Nesseris, MDa \\ Luca Caprili, MD \\ Gaetano Thiene, $M D^{b}$ \\ Gino Gerosa, MD
}

One illustration is available online. 7

From the Departments of Cardiovascular Surgery $^{\mathrm{a}}$ and Pathology, ${ }^{\mathrm{b}}$ University of Padua Medical School, Padua, Italy

Supported by grants of Istituto Superiore di Sanità and Ministero Istruzione Università e Ricerca and by Regione Veneto, Venice, Italy.

Received for publication Jan 10, 2004; revisions received June 11, 2004; accepted for publication June 21, 2004.

Address for reprints: Gino Gerosa, MD, Department of Cardiovascular Surgery, Via Giustiniani, 2, 35128, Padova, Italy (Email: gino.gerosa@unipd.it).

J Thorac Cardiovasc Surg 2005;129:322-9

$0022-5223 / \$ 30.00$

Copyright $(9) 2005$ by The American Association for Thoracic Surgery

doi:10.1016/j.jtcvs.2004.06.034
Background: We analyzed the intermediate experience, survival, and prosthetic complications of patients who received the Biocor valve, a new-generation porcine valve, in the mitral position.

Methods: At the University of Padua, between May 1992 and January 2004, 154 consecutive patients (102 female and 52 male patients; mean age, $72.3 \pm 6$ years; age range, 37-86 years) received 158 mitral Biocor prostheses (Biocor Industria e Pesguisa Ltda, Belo Horizonte, Brazil). Thirty-five percent of the patients had previous mitral operations, $24 \%$ had coronary artery bypass grafting, and 34.6\% had other procedures. Median preoperative New York Heart Association class was III. Echocardiography was performed in $75 \%$ of the long-term survivors. Follow-up included 609.4 patient-years and was $100 \%$ complete, with a median time of 4 patient-years (range, 0.02-11.3 years). At 8 years, 20 (14\%) of 142 operative survivors were still at risk.

Results: Early mortality was $13.6 \%$. According to univariate analysis, New York Heart Association class III to IV, ejection fraction of less than $40 \%$, urgency, male sex, and coronary artery bypass grafting were significant perioperative risk factors. Eight- and 10-year actuarial survival was $51.1 \% \pm 5.6 \%$ (40 deaths). Eight-year actuarial freedom from valve-related death, thromboembolism, anticoagulantrelated hemorrhage, endocarditis, paravalvular leak, and valve-related complications were $85.2 \% \pm 5 \%, 85.7 \% \pm 4.4 \%, 92.6 \% \pm 3.7 \%, 94.1 \% \pm 3 \%, 91.8 \% \pm$ $3 \%$, and $70.2 \% \pm 5.7 \%$, respectively. Freedom from structural valve deterioration was $100 \%$. Actual freedom from reoperation was $93.2 \% \pm 2.2 \%$. By Doppler echocardiography, the peak and mean transprosthetic gradients were $15 \pm 5 \mathrm{~mm} \mathrm{Hg}$ and $6.3 \pm 3 \mathrm{~mm} \mathrm{Hg}$, respectively (mean follow-up, $4.2 \pm 2.7$ years).

Conclusion: At intermediate follow-up, the Biocor prosthesis in the mitral position showed excellent results in terms of valve durability when compared with other second-generation tissue valves.

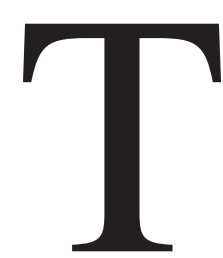

he major complication of porcine tissue valves is structural valve deterioration (SVD) aggravated by younger age and mitral position. A delay of this complication with the second-generation tissue valves has been observed as a result of improved valve engineering and mitigation of mineralization by an anticalcification treatment. ${ }^{1}$ The Biocor prosthesis (Biocor Industria e Pesguisa Ltda, Belo Horizonte, Brazil) is a porcine valve fixed in glutaraldehyde at low pressure without anticalcification treatment. The design is aimed to improve tissue durability: 3 
TABLE 1. Demographics

\begin{tabular}{lc}
\hline Variables & No. \\
\hline Prostheses/patients & $158 / 154$ \\
Age, y (mean \pm SD [median, range]) & $72.3 \pm 6[72.6,37-86]$ \\
Male/female & $102(66 \%) / 52(34 \%)$ \\
Sinus rhythm & $46(29 \%)$ \\
Atrial fibrillation & $102(64 \%)$ \\
Pacemaker because of heart block & $10(6.5 \%)$ \\
NYHA I-II & $44(28 \%)$ \\
NYHA III-IV & $114(72 \%)$ \\
Degenerative valvular disease & $34(22 \%)$ \\
Ischemic valvular disease & $17(11 \%)$ \\
Previous valvular repair & $12(7.7 \%)$ \\
Rheumatic valve disease & $38(24.5 \%)$ \\
Previous mitral valve replacement & $40(25 \%)$ \\
Active endocarditis & $3(1.8 \%)$ \\
Previous endocarditis & $6(3.8 \%)$ \\
Stroke before the operation & $26(16 \%)$ \\
Mean pulmonary pressure $>30$ mm Hg & $57(36 \%)$ \\
Left ventricular function $<40 \%$ & $7(4.4 \%)$ \\
Chronic obstructive pulmonary disease & $18(11 \%)$ \\
Previous heart surgery & $60(38 \%)$ \\
Urgent intervention* & $25(16 \%)$ \\
Associated procedures & \\
Coronary disease & $38(24 \%)$ \\
Tricuspid valve repair & $35(22 \%)$ \\
Internal carotid artery & $4(2.5 \%)$ \\
$\quad$ endarterectomy & \\
Radiofrequency ablation to restore & $4(2.5 \%)$ \\
$\quad$ sinus rhythm & $12(7.6 \%)$ \\
Others & \\
\hline
\end{tabular}

NYHA, New York Heart Association.

*Within 48 hours from hospital admission.

leaflets of similar size are separately mounted on a flexible acetyl copolymer stent, and this suture is covered with a pericardial sheet. The valve has been used in our institution since 1992.

The aim of this study was to analyze the intermediate clinical performance, complication rate, and hemodynamic performance of the Biocor porcine bioprosthesis implanted in the isolated mitral position.

\section{Patients and Methods}

Between May 1992 and January 2004, 274 Biocor valves were implanted in the mitral position. One hundred fifty-eight were isolated Biocor mitral prostheses, 59 were double mitral-aortic Biocor prostheses, and 3 were double mitral-tricuspid Biocor prostheses; the remaining valves were mixed with other prostheses or plastic repairs. We focused on 154 consecutive patients (102 female and 52 male patients; mean age, $72.3 \pm 6$ years; median age, 72.6 years; age range, 37-86 years) who underwent 158 isolated mitral heart valve replacements. The analysis was prosthesis oriented. Four patients who received a new isolated Biocor valve at reoperation were entered twice in the statistical analysis.
TABLE 2. Cause of death

\begin{tabular}{|c|c|c|}
\hline Mode of death & & No. \\
\hline \multirow{5}{*}{$\begin{array}{l}\text { Perioperative death: } \\
21(13.6 \%) \text { patients }\end{array}$} & Cardiac related & $15(71 \%)$ \\
\hline & Neurologic & $1(5 \%)$ \\
\hline & Sepsis & $1(5 \%)$ \\
\hline & Other noncardiac & $3(14 \%)$ \\
\hline & Respiratory failure & $1(5 \%)$ \\
\hline \multirow{7}{*}{$\begin{array}{l}\text { Late deaths: } 40(30 \%) \\
\text { patients }(10 \% \\
\text { patient-years) }\end{array}$} & $\begin{array}{l}\text { Cardiac related }(4.6 \% / \\
\text { patient-year) }\end{array}$ & $28(70 \%)$ \\
\hline & $\begin{array}{l}\text { Acute endocarditis }(0.16 \% / \\
\text { patient-year) }\end{array}$ & $1(2.5 \%)$ \\
\hline & $\begin{array}{l}\text { Thromboembolism (0.3\%/ } \\
\text { patient-year) }\end{array}$ & $2(5 \%)$ \\
\hline & $\begin{array}{l}\text { Cerebral hemorrhage }(0.3 \% / \\
\text { patient-year) }\end{array}$ & $2(5 \%)$ \\
\hline & $\begin{array}{l}\text { Gastrointestinal hemorrhage } \\
(0.1 \% / \text { patient-year })\end{array}$ & $1(2.5 \%)$ \\
\hline & $\begin{array}{l}\text { Unknown }(0.1 \% / \text { patient- } \\
\text { year) }\end{array}$ & $1(2.5 \%)$ \\
\hline & $\begin{array}{l}\text { Other noncardiac }(0.8 \% / \\
\text { patient-year) }\end{array}$ & $5(12.5 \%)$ \\
\hline
\end{tabular}

*Including perioperative deaths.

The data were prospectively collected. Patients' demographic data are detailed in Table 1.

The median New York Heart Association (NYHA) functional class was III (mean value, $2.5 \pm 0.8$ ). Sixty (38\%) patients had previous surgical procedures: mitral valve replacement (40 patients), mitral valve repair (12 patients), myocardial revascularization (5 patients), and other procedures (3 patients). The mean mitral prosthesis size was $30 \pm 1.4 \mathrm{~mm}$ (median, $31 \mathrm{~mm}$; range, 27-33 mm). Explanted bioprostheses underwent pathologic examination.

A paraseptal atrial incision, interrupted sutures, and posterior chordal preservation were routinely used. Oral anticoagulation (international normalized ratio, 2.0-3.0) was continued up to the third postoperative month unless atrial fibrillation or atrioventricular dilatation was present.

\section{Echocardiographic Analysis}

Between June 2000 and January 2004, 73 patients (73/97 [75\%]) underwent 122 consecutive 2-dimensional echocardiograms. Thirty-four patients underwent 2 echocardiograms, 11 patients underwent 3 echocardiograms, and 4 patients underwent 4 echocardiograms, respectively. The mean echocardiographic follow-up time was $4.2 \pm 2.7$ years, and the median was 4.2 years (range, $0.8-10$ years). Twenty-five percent of the echocardiograms were performed within 1.7 years of the operation, and $25 \%$ were performed 5.7 years after the operation. The simplified Bernoulli equation was used to calculate pressure prosthetic gradients. Left ventricular volumes were calculated by an ellipsoid biplane area-length method. ${ }^{2}$ Left ventricular myocardial mass was calculated by multiplying the myocardial volume by the specific weight of myocardial muscle $(1.05 \mathrm{~g} / \mathrm{mL})$. The left ventricle was defined as normal when the 


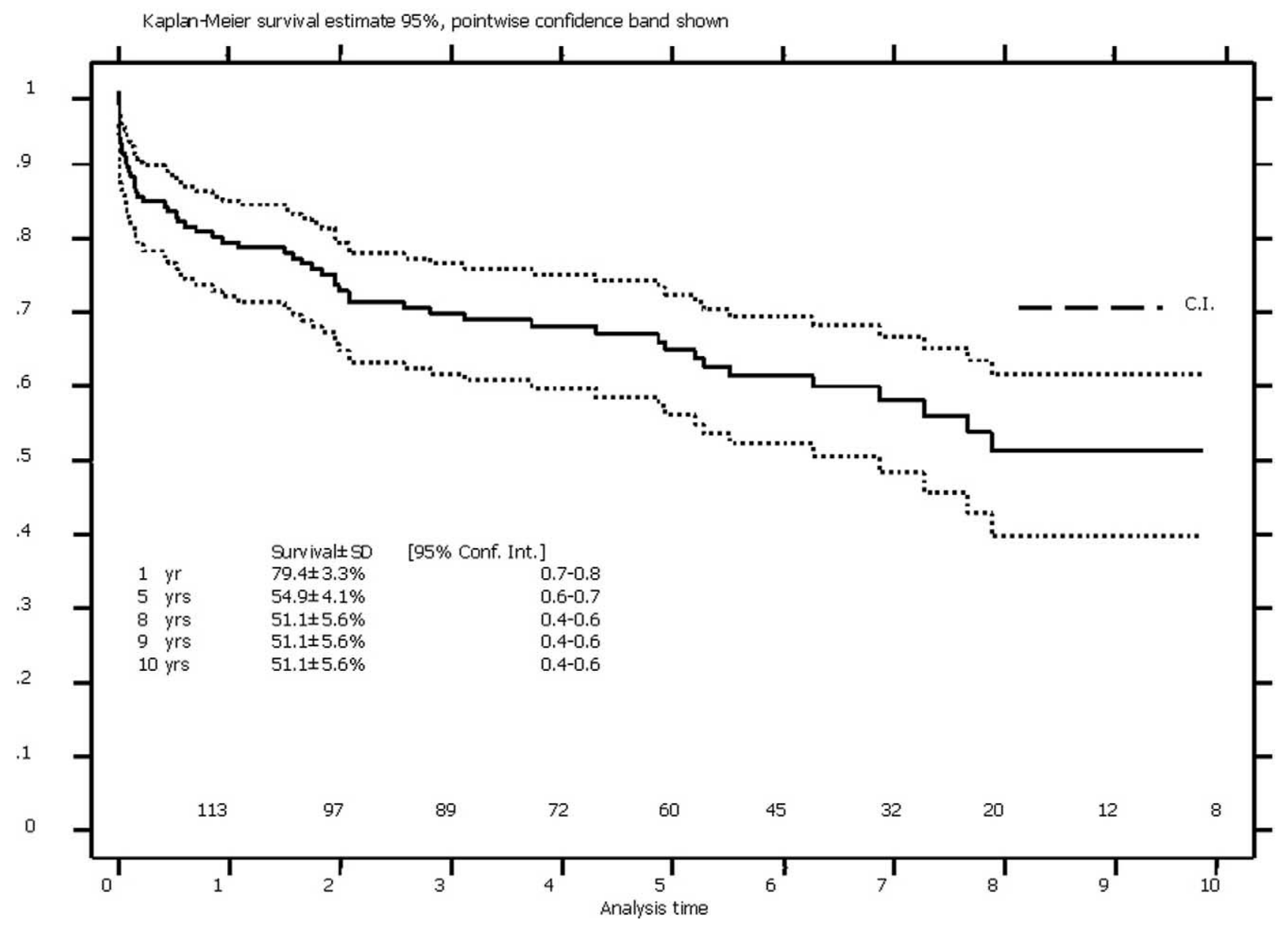

Figure 1. Eight-year actuarial survival.

TABLE 3. Overall 8-year Kaplan-Meier freedom from valverelated events*

\begin{tabular}{lcc}
\hline & $\begin{array}{c}\text { Actuarial estimate } \pm \\
\text { SD }\end{array}$ & $\begin{array}{c}\text { Linearized rate (\%/ } \\
\text { patient-year) } \pm \text { SD }\end{array}$ \\
\hline Valve-related death & $85.2 \% \pm 5 \%$ & $10 \pm 0.43$ \\
Paravalvular leak & $91.8 \% \pm 3 \%$ & $1.5 \pm 0.52$ \\
Reoperation & $91.1 \% \pm 3 \%$ & $1.5 \pm 0.52$ \\
& (actual estimate, & \\
& $93.2 \% \pm 2.2 \%)$ & \\
Thromboembolism & $85.7 \% \pm 4.4 \%$ & $2.0 \pm 0.59$ \\
Endocarditis & $94.1 \% \pm 3 \%$ & $0.83 \pm 0.37$ \\
Major bleeding & $92.6 \% \pm 3.7 \%$ & $1.11 \pm 0.41$ \\
Valve-related & $70.2 \% \pm 5.7 \%$ & $4.6 \pm 0.96$ \\
$\quad$ complications & & \\
\hline
\end{tabular}

*No events recorded beyond 8 years.

left ventricular end-diastolic volume was less than $70 \mathrm{~mL} / \mathrm{m}^{2}$ and the mass/volume ratio was between 0.8 and $1.2 \mathrm{~g} / \mathrm{mL}$. The ejection fraction (percentage) was calculated as follows: (Enddiastolic volume - End-systolic volume)/End-diastolic volume.

\section{Patient Follow-up}

The follow-up period, including direct visits, questionnaires, and telephone interviews, was closed in January 2004, and the cumulative time was 609.4 patient-years; it was $100 \%$ complete. Mean follow-up time was $4.4 \pm 0.027$ years, and the median was 4 years (range, 0.02-11.3 years).

\section{Statistical Analysis}

The guidelines of Edmunds and colleagues ${ }^{3}$ for morbidity and mortality reporting were used for defining postoperative complications and prosthesis-related events. The linearized rate of postoperative complications and prosthesis-related events was expressed as percentage per patient-year. The $\chi^{2}$ test was used for statistical comparison.

Estimate of overall survival was calculated by the KaplanMeier method and expressed as the percentage \pm SE or the percentage $\pm 95 \%$ confidence interval (CI). Fifteen patients were younger than 65 years of age (Figure E1). No events were recorded beyond 8 years of follow-up; nonetheless, our report was limited to 8 years, with 20 patients at risk (14\% of survivors). Actual complication freedom was calculated by the method of Grunkemeier and associates. 4 


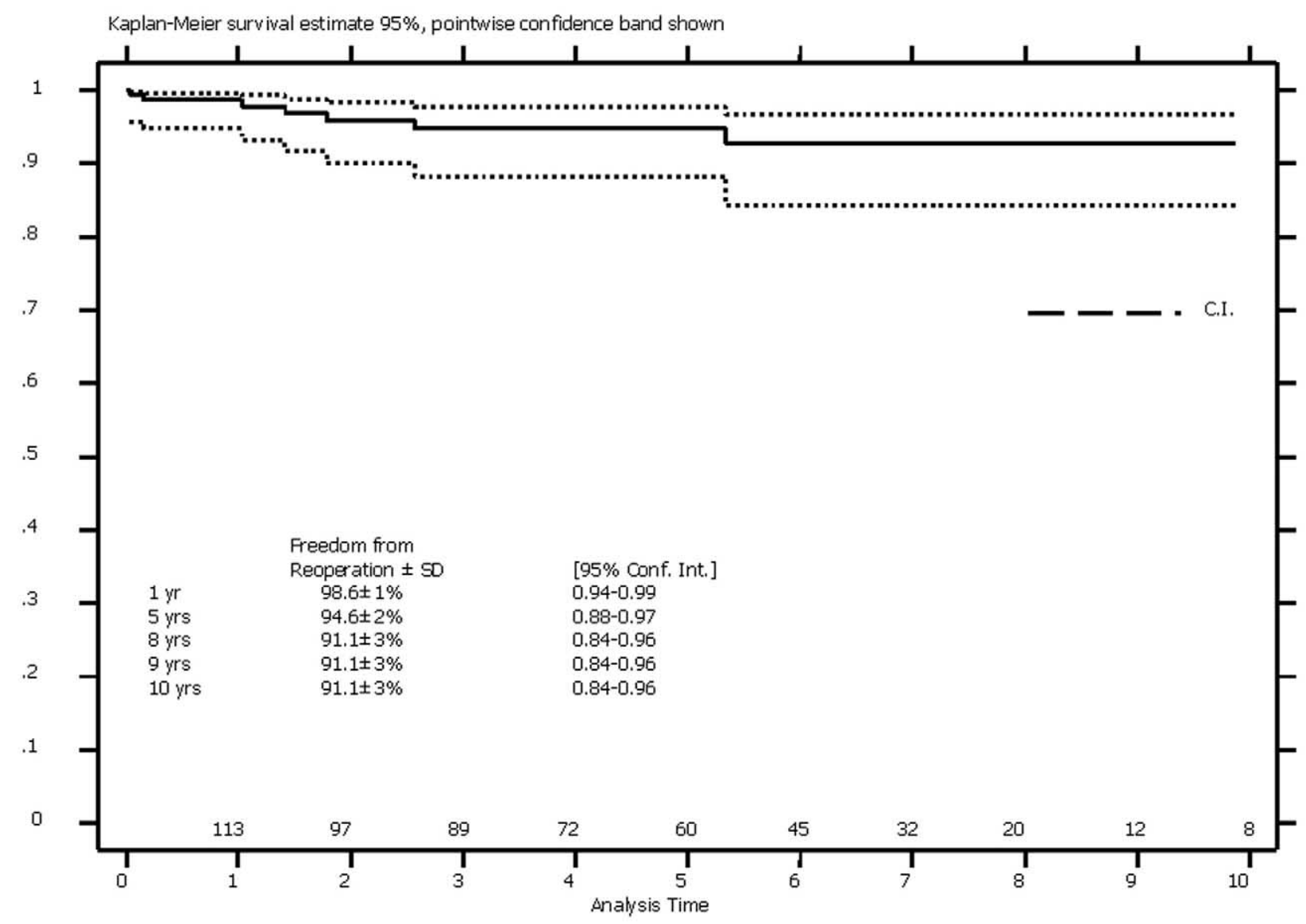

Figure 2. Eight-year actuarial freedom from reoperation.

\section{Results}

\section{Operative Results}

Perioperative mortality was $13.6 \%$ (95\% CI, 5.9\%-16\%), affecting 21 patients in 158 operations. The male/female ratio was 10:11 (mean age, $72.3 \pm 1$ years; range, 62-78 years). Nineteen (90\%) patients were in NYHA class III to IV , 43\% (9/21) had an urgent or emergency operation, 52\% had concomitant procedures (7 CABGs, 2 internal carotid thromboendarterectomies, and 2 atrial thrombectomies), $33 \%(7 / 21)$ had a previous cardiac operation, and 24\% $(5 / 21)$ had an ejection fraction of less than $40 \%$.

NYHA status III to IV, low ejection fraction, urgent operation, male sex, and myocardial revascularization were identified as significant univariate risk factors $(P<.05)$. Causes of death are detailed in Table 2.

\section{Survival}

Overall survival was $51.1 \% \pm 5.6 \%$ (Figure 1). There were 40 late deaths: $28(70 \%)$ were cardiac related, and $8(20 \%)$ were exclusively valve related. The survival of younger patients ( $\leq 65$ years) was better than the survival of older patients $(65.2 \%$ [3 patients at risk] vs $49.4 \%$ [17 patients at risk], $P=.4$ ). Actuarial freedom from valverelated death was $85.2 \% \pm 5 \%$ (linearized rate of $1.0 \%$ per patient-year, Table 3). Causes of late death are detailed in Table 2. At the end of follow-up, mean NYHA class was $1.97,82 \%$ of patients were receiving anticoagulants (80/97), and 50\% were in sinus rhythm (49/97). Eighty-four percent of patients in NYHA class III to IV improved, and $84 \%$ of patients in NYHA class I to II remained in the same class.

\section{Thromboembolism}

Twelve major thromboembolic events occurred in 12 patients, 2 early and 10 late. Among these patients, 25\% had an embolic stroke before the operation; 9 patients had atrial fibrillation and were given anticoagulant therapy. Embolism was fatal in 3 patients. Actuarial freedom from thromboembolism was $85.7 \% \pm 4.4 \%$ (Table 3 ).

\section{Hemorrhagic Events}

Seven patients had anticoagulation-related major hemorrhage, which was fatal in 3 cases. Actuarial freedom from 


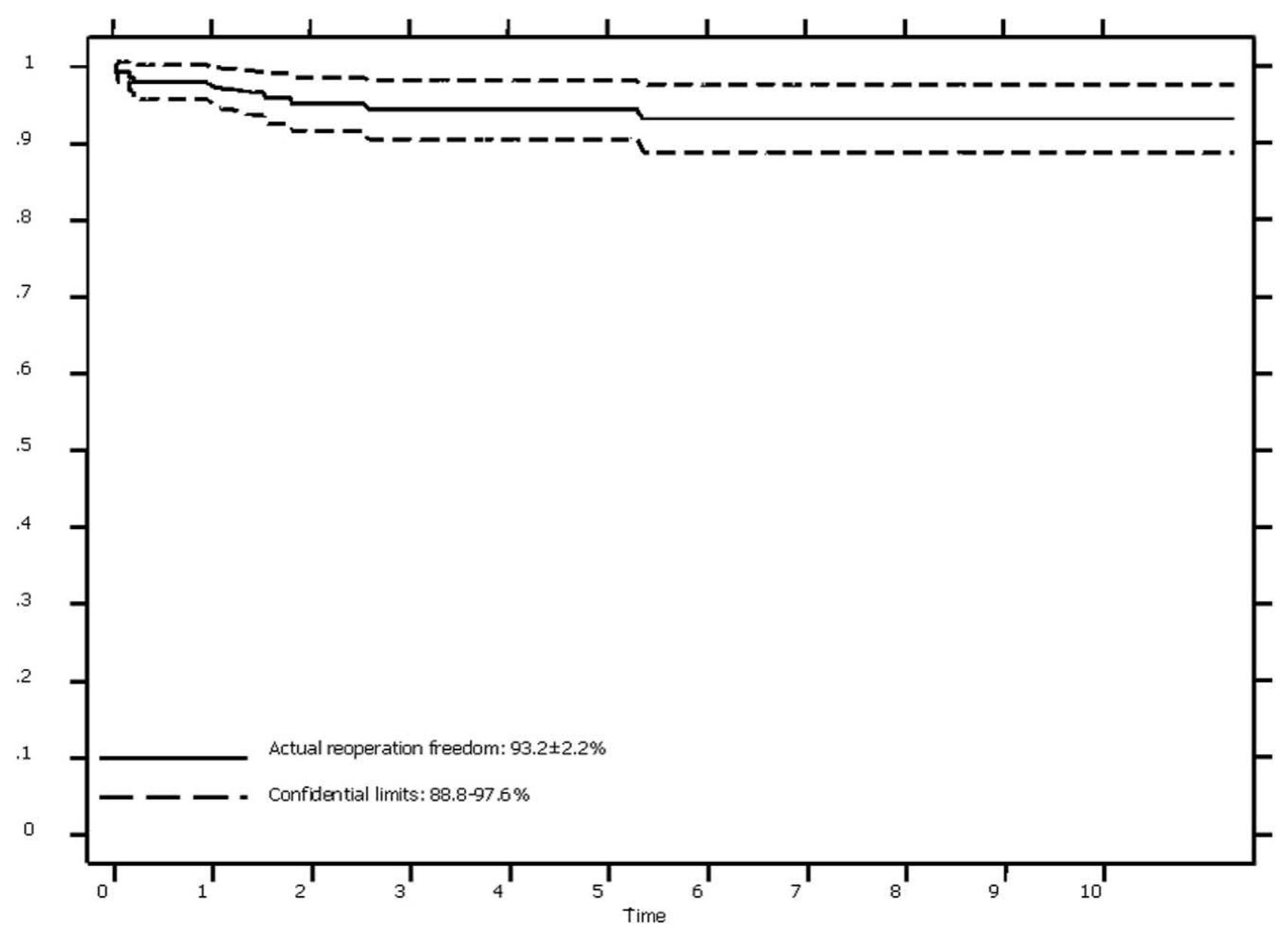

Figure 3. Eight-year actual freedom from reoperation. Dotted lines depict the $\mathrm{CI}$.

TABLE 4. Echocardiographic data

\begin{tabular}{|c|c|c|c|c|c|c|c|c|c|c|}
\hline Valve size & No. & BSA, $\mathrm{m}^{2}$ & $\begin{array}{c}\mathbf{P} \\
\text { gradient, } \\
\mathrm{mm} \mathrm{Hg}\end{array}$ & $\begin{array}{c}\mathbf{M} \\
\text { gradient, } \\
\mathrm{mm} \mathrm{Hg}\end{array}$ & $E F, \%$ & $\begin{array}{l}\text { M/N ratio, } \\
\text { g/mL }\end{array}$ & $\begin{array}{l}\text { LVEDV, } \\
\mathrm{mL} / \mathrm{m}^{2}\end{array}$ & $\begin{array}{l}\text { LAC, } \\
\mathrm{mL} / \mathrm{m}^{2}\end{array}$ & $\begin{array}{l}\text { Indexed EOA, } \\
\mathrm{cm}^{2} / \mathrm{m}^{2} \text { (no.) }\end{array}$ & EOA, $\mathrm{cm}^{2}$ (no.) \\
\hline 29 & 50 & $1.6 \pm 0.13$ & $16 \pm 5$ & $6.7 \pm 3$ & $55 \pm 10$ & $1.15 \pm 0.1$ & $73 \pm 23$ & $69 \pm 22$ & $1.9 \pm 0.64(31)$ & $3.06 \pm 0.88(31)$ \\
\hline 31 & 47 & $1.7 \pm 0.16$ & $15 \pm 5$ & $6.2 \pm 3$ & $51 \pm 11$ & $1.15 \pm 0.17$ & $77 \pm 33$ & $100 \pm 63$ & $2.0 \pm 0.55(28)$ & $3.27 \pm 1.4(28)$ \\
\hline 33 & 25 & $1.8 \pm 0.15$ & $12.6 \pm 6$ & $5.4 \pm 2.4$ & $53 \pm 13$ & $1 \pm 0.19$ & $91 \pm 50$ & $91 \pm 67$ & $1.8 \pm 0.55(18)$ & $3.63 \pm 1.57(18)$ \\
\hline Mean & 122 & $1.7 \pm 0.16$ & $15 \pm 5$ & $6.3 \pm 3$ & $53.6 \pm 11$ & $1.11 \pm 0.9$ & $77 \pm 33$ & $85 \pm 53$ & $1.9 \pm 0.58(77)$ & $3.26 \pm 1.23(77)$ \\
\hline
\end{tabular}

$B S A$, Body surface area; $E F$, ejection fraction; $M / V$, mass/volume; $L V E D V$, left ventricular end-diastolic volume; $L A C$, left atrial chamber; $E O A$, effective orifice area.

anticoagulant-related hemorrhage was $92.6 \% \pm 3.7 \%$ (Table 3).

\section{Paravalvular Leak}

Nine patients were affected, and 5 underwent reoperation. Dehiscence was mostly related to previous interventions: SVD (3 patients), percutaneous valvuloplasty (1 patient), and paravalvular leak (1 patient). One patient had previous endocarditis and one had ischemic valve disease as predisposing factors. Two further cases oc- curred in a rheumatic and a dysplastic valve. The median interval time between implant and paravalvular leak diagnosis was 1 year (range, 1.9 months to 5.5 years). An atrial thrombus was observed in one patient undergoing reoperation. Actuarial freedom from leak was $91.8 \% \pm$ $3 \%$ (Table 3).

\section{Endocarditis}

Five patients had endocarditis. Four were medically treated, with 50\% mortality. A single patient underwent reoperation 

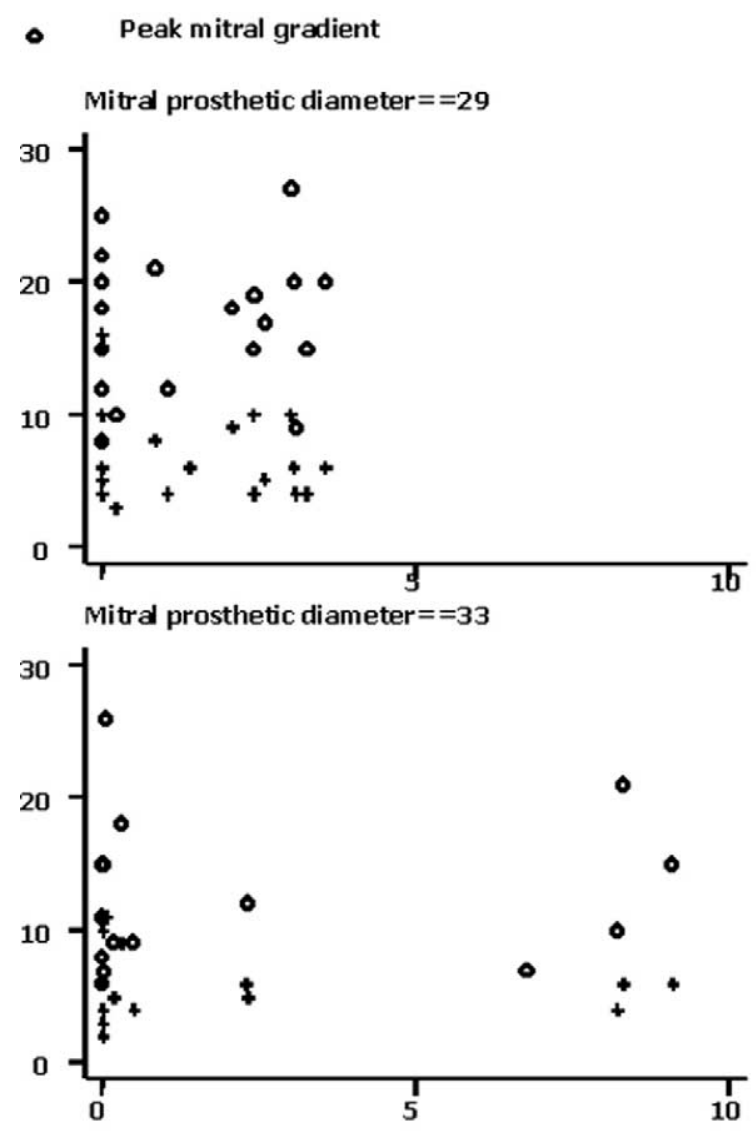

$+\quad$ Mean mitral gradient
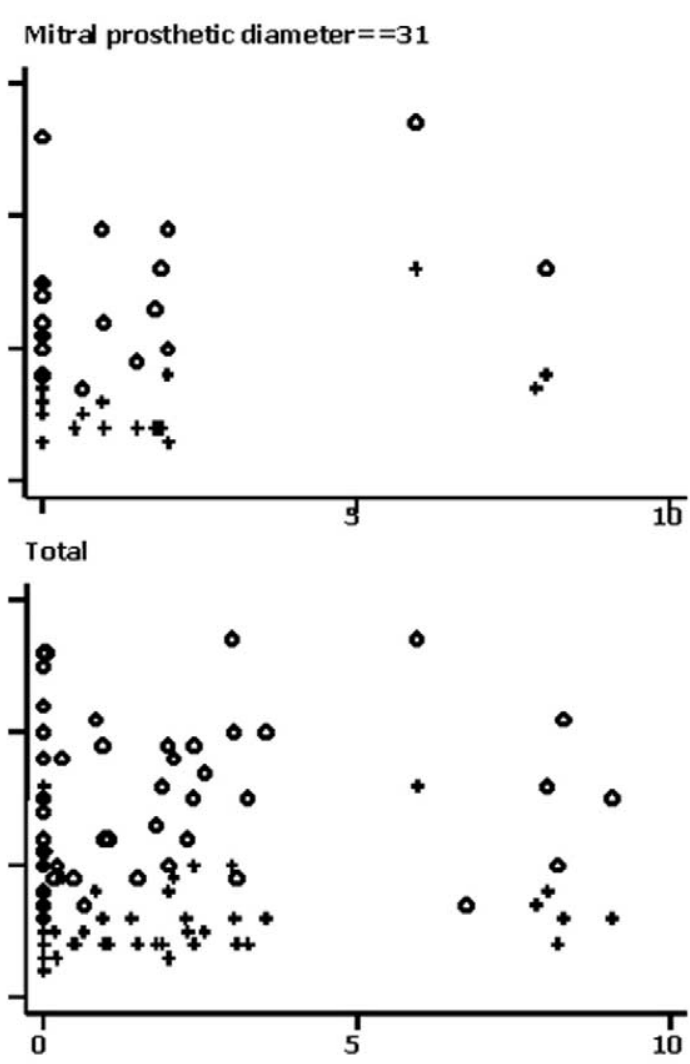

Interval between initial and repeated echos

Figure 4. Time-related peak and mean echocardiographic gradients in patients with repeated echocardiograms.

with another Biocor valve. Actuarial freedom from endocarditis was $94.1 \% \pm 3 \%$ at 8 years (Table 3 ).

\section{SVD}

None of the Biocor prostheses implanted in the mitral position were replaced because of SVD. All the replaced Biocor prostheses underwent pathologic examination, and none showed signs of cusp calcification.

\section{Reoperations}

Nine patients underwent reoperation: 5 because of prosthetic dehiscence, 2 because of disease progression in the aortic valve, 1 because of acute endocarditis, and 1 because of atrioventricular pseudoaneurysm. The very late reoperations, after 2.5 and 5.3 years, respectively, were due to progression of aortic valve disease. The dehiscence-related reoperations were performed between 1.3 and 1.8 years, with a single exception (within 2 months). Pseudoaneurysm was repaired after 10 days, and endocarditis was treated after 73 days. Actuarial (Table 3) and actual freedom from reoperation were $91.1 \% \pm 3 \%$ and $93.2 \% \pm 2.2 \%(95 \% \mathrm{CI}$, $88.8 \%-97.6 \%$ ), respectively (Figures 2 and 3 ).

\section{Valve-Related Complications}

Five patients had more complications. There were 28 first events, including hemorrhage, thromboembolism, endocarditis, paravalvular leak, and reoperation, with the exclusion of the 2 reoperations resulting from progression of disease of the aortic valve. Actuarial freedom was $70.2 \% \pm 5.7 \%$ (Table 3).

\section{Echocardiography}

Mean and peak transprosthetic gradients for all valves were $6.3 \pm 3 \mathrm{~mm} \mathrm{Hg}$ and $15 \pm 5 \mathrm{~mm} \mathrm{Hg}$, respectively. Ejection fraction, average body surface area, mass/volume ratio, left ventricular end-diastolic volume, volume of the left atrial chamber, and effective orifice area are summarized in Table 4. Comparing echocardiographic data of patients with a valve functioning for more versus less than 6 years, mean and peak gradients were similar $(P=.7)$. In the 49 patients who underwent repeated echocardiography, the valves showed, over time, stable mean and peak transvalvular gradients (Figure 4). Thirty patients had pulmonary hypertension, and the mean value of peak pulmonary artery 
pressure was $42 \pm 13 \mathrm{~mm} \mathrm{Hg}$. Thirty-two patients showed mild valve incompetence, with a mean value of $1.25 \pm 0.6$.

\section{Discussion}

In the time interval of this study, 253 tissue valves, including 158 Biocor, 18 Biocor Epic, 9 Hancock II, 25 CarpentierEdwards Perimount, 20 Labcor, and other prostheses were implanted in an isolated mitral position. Our indications for the use of bioprostheses were identical to those reported by the American Heart Association, ${ }^{5}$ finally depending on operating table findings and prosthesis availability.

The purpose of our study was to verify the advantage of the mitral Biocor prosthesis, monitoring the incidence of SVD and other prosthesis-related complications. Calcification is the main cause of biologic prosthesis dysfunction and reoperation. ${ }^{6}$ A less common cause of early structural deterioration is commissural dehiscence, which affects mostly mitral bioprostheses. ${ }^{7}$

Younger operative age, chronic renal failure, and mitral position have been identified as independent risk factors for SVD. ${ }^{8}$ Therefore, patients older than 65 or 70 years are usually selected for mitral valve replacement with a tissue valve because in these patients the valve should function longer than the expected life.

In 1982, the second-generation porcine bioprosthesis, including the Carpentier-Edwards supra-annular, Hancock II, and Biocor prostheses, was introduced on the market, with the aim to reduce the SVD incidence and to extend the age range of successful clinical use. Contrary to the Hancock II and Carpentier-Edwards prostheses, the Biocor prosthesis did not receive an anticalcification treatment. Until now, long-term results in the isolated mitral position have been reported by Myken, ${ }^{9}$ Kirali, ${ }^{10}$ and their associates.

\section{Clinical Results}

Perioperative mortality (13.6\%) was related to the advanced age of our series (median age, 72 years) and to inadequate risk factor neutralization. ${ }^{8}$ Thirty-seven percent of our patients had a previous operation, and $44 \%$ had an urgent operation. Other frequently identified risk factors were older age, operative era, and NYHA class. On the contrary, the late survival of our older patients was excellent (51.6\%), and only Kirali and associates ${ }^{10}$ reported a better overall long-term survival (77\% at 10 years) in a significantly younger (average, 48 years; $P=.0001$ ) patient population.

In our series the mean transprosthetic gradient was $6.3 \pm$ $3 \mathrm{~mm} \mathrm{Hg}$, and it was inversely related to prosthesis size. Thirty-two patients showed mild incompetence. In the patients who underwent consecutive echocardiography, the recordings showed hemodynamic stability over time. Unfortunately, few articles report sufficient echocardiographic data on second-generation mitral bioprostheses for compar- ison, and reports on time-related changes of the valvular gradients are missing.

Overall freedom from valve-related complication is similar to that obtained with other tissue valves. ${ }^{1,7,11,12}$

The unique valve-related cause of Biocor reoperation was paravalvular leak, with an incidence similar to that observed by Myken and coworkers ${ }^{9}$ with the same valve. This complication, which is due to several patient-intrinsic factors, technical factors, or both, occurred in our series mostly after reoperation for SVD or prosthetic paravalvular leak, and therefore we do not think there are enough data to link it to prosthetic factors.

\section{Freedom from SVD}

There were no reoperations because of SVD, and furthermore, no patient showed signs of dysfunction caused by dystrophic calcification at 2-dimensional echocardiography. Published experiences with this prosthesis were also satisfactory. Myken and coworkers ${ }^{9}$ reported $100 \%$ SVD freedom in the mitral position at 15 years in patients older than 61 years, and Kirali and colleagues ${ }^{10}$ reported a $95 \%$ freedom in patients older than 65 years.

Commissural dehiscence complicated the functioning of several models of tissue valve, ${ }^{1,7,13,14}$ occurring mostly in larger mitral valves being subjected to higher mechanical stress. This complication was never observed in our explanted Biocor prostheses. We think that the valve design, protecting the suture of the 3 valve leaflets with a strip of pericardium, might offer some advantage.

\section{Conclusion}

The design-related favorable lack of commissural dehiscence and the overall valve-related complication incidence similar to that of other porcine and pericardial valves of the last generation make the Biocor valve a reliable choice when a higher valve stress can be anticipated, as in the mitral position and in relatively active patients.

We thank Annarita Miola for assistance in preparing the echocardiographic data collection, and Nicola Paccagnella for preparation of the figures.

\section{References}

1. David TE, Ivanov J, Armstrong S, Feindel CM, Cohen G. Late results of heart valve replacement with the Hancock II bioprosthesis. J Thorac Cardiovasc Surg. 2001;121:268-77.

2. Wyatt HL, Heng MK, Meerbaum S, Gueret P, Hestenes J, Dula E, et al. Cross-sectional echocardiography. II. Analysis of mathematic models for quantifying volume of the formalin-fixed left ventricle. Circulation. 1980; 61:1119-25.

3. Edmunds LH Jr, Clark RE, Cohn LH, Grunkemeier GL, Miller DC, Weisel RD. Guidelines for reporting morbidity and mortality after cardiac valvular operations. Ad Hoc Liaison Committee for Standardizing Definitions of Prosthetic Heart Valve Morbidity of The American Association for Thoracic Surgery and The Society of Thoracic Surgeons. J Thorac Cardiovasc Surg. 1996;112:708-11.

4. Grunkemeier GL, Anderson RP, Miller DC, Starr A. Time related analysis of nonfatal heart valves complication: cumulative incidence 
(actual) vs. Kaplan-Meier (actuarial). Circulation. 1997;96(suppl II):II70-5.

5. Bonow RO, Carabello B, de-Leon AC Jr, Edmunds LH Jr, Fedderly BJ, Freed MD, et al. Guidelines for the management of patients with valvular heart disease: executive summary. A report of the American College of Cardiology/American Heart Association Task Force on Practice Guidelines (Committee on Management of Patients with Valvular Heart Disease). Circulation. 1998;98:1949-84.

6. Burdon TA, Miller DC, Oyer PE, Mitchell RS, Stinson EB, Starnes VA, et al. Durability of porcine valves at fifteen years in a representative North American population. J Thorac Cardiovasc Surg. 1992; 103:238-52.

7. Nistal JF, Hurle A, Gutierrez JA, Mazorra F, Revuelta JM. Commissural dehiscence of Carpentier-Edwards mitral bioprostheses. Explant analysis and pathogenesis. J Thorac Cardiovasc Surg. 1995;110:688-96.

8. Jamieson WR, Burr LH, Miyagishima RT, Janusz MT, Fradet GJ, Lichtenstein SV, et al. Reoperation for bioprosthetic mitral structural failure: risk assessment. Circulation. 2003;108(suppl II):II98-102.
9. Myken P, Bech Hanssen O, Phipps B, Caidahl K. Fifteen years follow up with the St. Jude Medical Biocor porcine bioprosthesis. J Heart Valve Dis. 2000;9:415-22.

10. Kirali K, Guler M, Tuncer A, Daglar B, Ipek G, Isik O, et al. Fifteen-year clinical experience with the Biocor porcine bioprostheses in the mitral position. Ann Thorac Surg. 2001;71:811-5.

11. Poirier NC, Pelletier LC, Pellerin M, Carrier M. 15-year experience with the Carpentier-Edwards pericardial bioprosthesis. Ann Thorac Surg. 1998;66(suppl):S57-61.

12. Rizzoli G, Bottio T, Thiene G, Toscano G, Casarotto D. Fifteen years durability of Hancock II porcine bioprostheses. J Thorac Cardiovasc Surg. 2003;126:66-74.

13. Jamieson WR, Burr LH, Janusz MT, Munro AI, Hayden RI, Miyagishima RT, et al. Carpentier-Edwards standard and supraannular porcine bioprostheses: comparison of technology. Ann Thorac Surg. 1999;67:10-7.

14. Jamieson WR, Lemieux MD, Sullivan JA, Munro AI, Metras J, Cartier PC. Medtronic intact porcine bioprosthesis: 10 years' experience. Ann Thorac Surg. 1998;66(suppl):S118-21.

Online-www.aats.org

Now you can get The Journal of Thoracic and Cardiovascular Surgery online. The Journal online brings you faster delivery time, easy searching of current and back issues, links to PubMed, AATS, WTSA, and other important sites, and more. Visit the Journal online today.

\section{Receive tables of contents by e-mail}

To receive the tables of contents by e-mail, sign up through our Web site at http://www.mosby.com/jtcvs

Choose E-mail Notification

Simply type your e-mail address in the box and click the Subscribe button. Alternatively, you may send an e-mail message to majordomo@mosby.com. Leave the subject line blank and type the following as the body of your message: subscribe jtcvs_toc You will receive an e-mail to confirm that you have been added to the mailing list.

Note that TOC e-mails will be sent out when a new issue is posted to the Web site. 


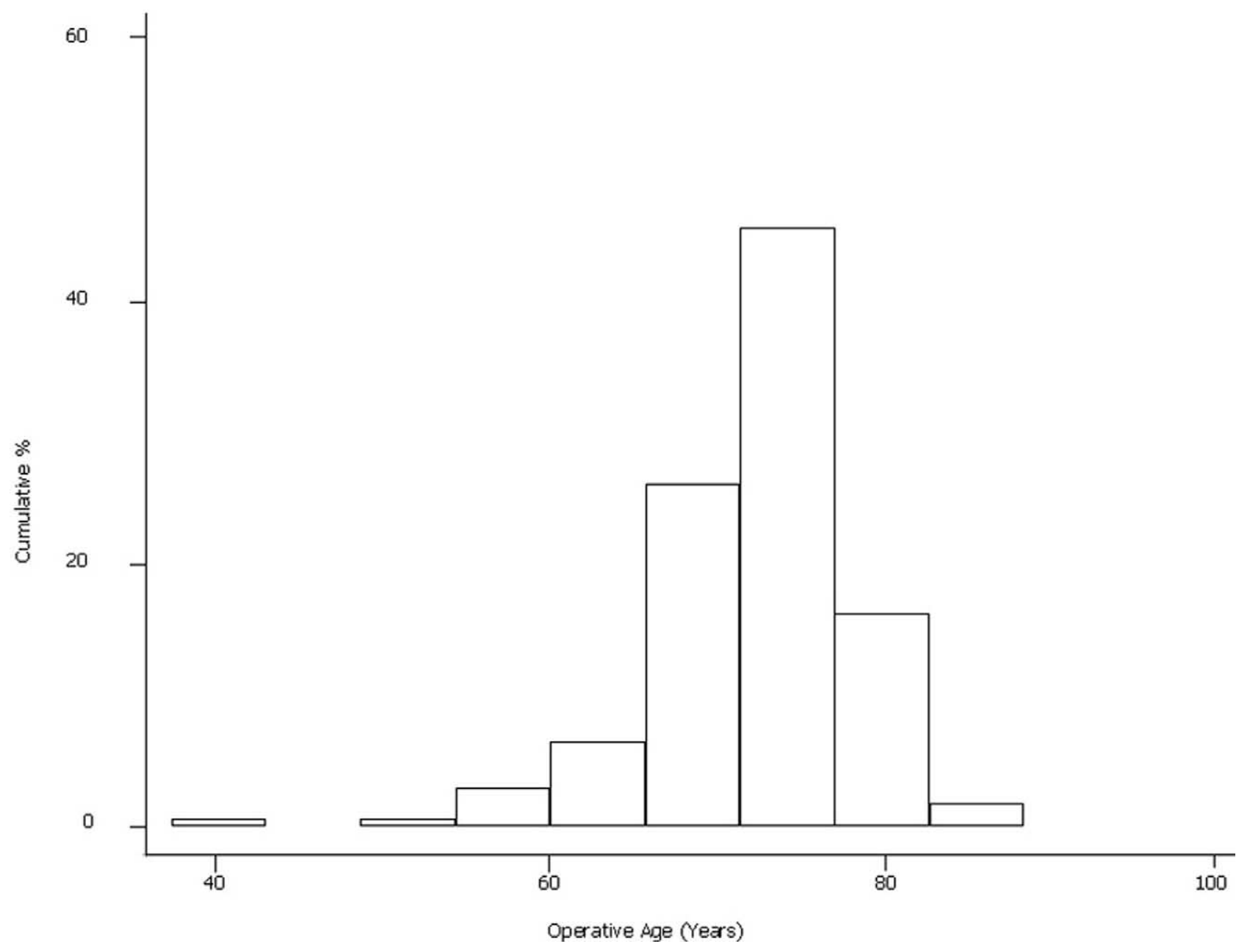

Figure E1. Cumulative age distribution. 